\title{
Filmlerle Hatırlamak: Toplumsal Travmaların Sinemada Temsil Edilişi - Sevcan Sönmez
}

\author{
Inceleyen: Batu Anadolu
}

Filmlerle Hatırlamak: Toplumsal Travmaların Sinemada Temsil Edilişi

Yazar: Sevcan Sönmez

Metis Yayınları, İstanbul: 2015, 168 s.

ISBN: 13 978-605-316-003-8

Alman yönetmen Michael Haneke, bir röportajında Steven Spielberg'in Schindler's List (Schindler'in Listesi, Steven Spielberg, 1993) filminde yer alan meşhur duş sahnesine atıfta bulunur (Calhoun, 2009). Ona göre filmde "duş başlı̆̆ından su mu yoksa gaz mı gelecek" sorusu ile yaratılan heyecan, Amerikalı izleyicinin naif beklentilerini tatmin ederken soykırımı sorumsuzca ele alır. Bu nedenle de izleyici, yaşanmış acı gerçekleri bir gösteri eşliğinde tüketir. Bu bakış açısını farklı yönlerden değerlendirmek mümkündür. Filmlerin, toplumsal bellekte yer edinmiş olaylara bakış açıları ne kadar farklılaşabilir? Sinema, bu bilincin oluşmasında nasıl bir rol edinir ve bu rolleri farklı kılan etmenler nelerdir? Ya da kisacası sinema, yaşanmışlıkların yeniden sunumunda nasıl bir rol oynar?

Sevcan Sönmez'in Metis Yayınları'ndan çıkan "Filmlerle Hatırlamak: Toplumsal Traumaların Sinemada Temsil Edilişi" isimli kitabı, yukarıda bahsi geçen sorunun Türkiye sinemasını kapsamında sorulmasını sağlar. Kitabın temeli, yazarın "Sinema ve Toplumsal Bellek: Türkiye Sinemasında Travmatik Temsiller" başlıklı doktora tezine dayanır. Tezin kısaltılmış ve derlenmiş bir versiyonu olarak karşımıza çıkan kitapta özellikle 1990 sonrası yeni bir döneme girdiği çeşitli kaynaklarda ifade edilen Türkiye Sineması' nda - Yeni Dönem Türkiye Sineması olarak da adlandırılabilir- tarihsel olayların ve bu olayların ortaya çıkardığı travmaların nasıl işlendiği incelenir: "Türkiye sineması artık bu çokuluslu, çok kültürlü toprakların gerçeklerine atıfta bulunuyordu. Ana akımdan kopuştu bu; yıllarca görmezden gelinenin görülmeye başlaması demekti" (s. 13).

Sönmez, kitabın giriş kısmını bellek, toplumsal bellek ve travma üzerine tanımlara ve farklı görüşlere ayırır. Bu kavramlar, tarih içerisindeki gelişimleri üzerinden günümüze farklı bakışlarla ve felsefi açıdan irdelenir. Özellikle toplumsal bellek konusuna gelmeden önce belleğin geçmişin olduğu gibi korunduğu bir alan değil, kişinin kendi tasarımı ile değiştirdiği bir alan olduğu vurgusu yapılır. Aslında bu bakış açısının, sinema ile olan benzerliği de göze çarpar. Gerçeklerden yola çıkan bir film, doğal olarak onun yaratıcısının ve içinde bulunduğu ideolojinin de bir temsilcisi olabilmektedir: "Evet, sinema bir eğlencelik, bir hikâye anlatım aracı, kitleleri manipüle etmenin en etkili araçlarından biri, bir endüstri ve bir ideolojik aygıt ve Adorno'dan beri biliyoruz ki kitle iletişim araçlarının en önemli yönleri ideolojik işlevleri" (s. 13). Ortaya çıkan filmin, tamamen objektif bir bakış açısına sahip olduğunu ya da yeni bir söylem ortaya koyamadığını söylemek mümkün değildir. Maurice Halbwachs'ın "en kişisel anıların bile sosyal grupların iletişimi üzerinden yapılandığı" görüşü üzerinden; filmlerin sadece yaratıcısının değil, onu izleyenlerin de eseri olduğu ve karşılıklı bir iletişimin 
gerçekleştiği söylenebilir. Yine Halbwachs'a göre toplumsal belleğin kalıcı olmasında "hatırlama figürleri" denilen olgular önemli yer oynarlar. Bu figürler zaman ve mekâna bağlılık, bir gruba bağl1lık ve kendine özgü bir süreç olarak yeniden kurulabilme özelliğidir (Aktaran: Assmann, 2001: 42). İlk iki olgu, bir deneyimin toplumsal belleğe aktarılmasında rol oynayan zaman, mekân ve toplumu nitelerken üçüncü olgu, bu deneyime dayanan toplumsal belleğin her dönem yeniden kurulacağını ifade eder. Yani toplumsal bellek sürekli olarak yeniden inşa edilir; bazı deneyimler ön plana çıkarılır, bazıları ise unutturulur. Böylece paylaşılan bellek üzerinden bir çarpıtma gerçekleştirilebilir: "En kişisel anılar bile, sadece sosyal grupların iletişimi ve etkileşimi üzerinden yapılanır" (s. 19).

Sönmez, kitabında bahsi geçen toplumsal bellek konusu üzerinden sinematografik temsillerin incelemesini yapar. Filmleri sadece içerikleri yönünden değil, biçemsel yönden de inceleyerek "anlatıların yardımıyla travmaların ortaya dökülmesi ve yüzleşme sağlanabilir mi?", "toplumsal bir hesaplaşma zemini kurulabilir mi?" gibi sorular sorar. Filmler, toplumsal olaylara eleştirel biçimde mi yaklaşırlar yoksa onlarla ilgili travmaları bastırma yönüne mi giderler. Ama en önemlisi; hangi şartlarda hangi yöntemler uygulanır?

Aranan cevaplara ulaşmak için bazı ana kaynaklardan faydalanılır ve içerik-biçim örüntüsü, bu kaynaklar üzerinden teker teker incelemeye tabi tutulur. E. Ann Kaplan ve Ban Wang'in "Trauma and Cinema" kitabı ve Judith Butler'ın "eleştirel imge kavramı" sıklıkla filmlerin incelenmesinde yer verilen kaynaklar olarak karşımıza çıkarlar.

Kitapta ele alınan filmlerin hepsi 1990'lı yıllardan sonra çekilmiş ve Türkiye'de genellikle tabu olarak görülmüş, henüz yüzleşilmemiş, kurbanlarının yas tutmalarına izin verilmemiş ve mağdurların susturulup egemenin dilinden konuşmak zorunda bırakıldıkları olayları konu alan yapımlardır. Gelecek Uzun Sürer (Özcan Alper, 2011), Press (Sedat Yılmaz, 2010) ve Işıklar Sönmesin (Reis Çelik, 1996) ile Güneydoğu Anadolu'daki çatışmaları, faili meçhulleri ve basına uygulanan sistematik şiddeti; Yazı Tura (Ŭ̆ur Yücel, 2004) ve Nefes: Vatan Sağolsun (Levent Semerci, 2009) ile benzer konuların bir bakıma daha geniş kesimlerden insanlara yansımasını, Salkım Hanım'ın Taneleri (Tomris Giritlioğlu, 1999) ve Güz Sancısı (Tomris Giritlioğlu, 2009) ile azınlıkların yaşadıkları sorunları, Eve Dönüşs̈Ömer Ŭ̆ur, 2006) ile 12 Eylül dönemi işkencelerini ve Sonbahar (Özcan Alper, 2008) ile F Tipi cezaevleri, büyük kapatılma ve tüm ülkenin hapishaneye dönüşmesi metaforunu işleyen filmler aracılığıyla hem yaşananların toplumsal bellekte bıraktığı izlere hem de bunların sinematografik yorumlarına yer verilir.

\section{Sinematografik Temsiller Hatırlayabilirler Mi?}

Kitapta incelenen ilk film Gelecek Uzun Sürer ile Sönmez, acıların kuşaktan kuşağa geçtiğine vurgu yaparak kalıtımsal bir travmadan söz eder. Güneydoğu Anadolu coğrafyasına sinen bu travmatik halin ortaya çıkarılma ve tedavi edilme yöntemlerinden biri de sinemadaki izleyicilik deneyimidir. Hikâye anlatan bir sanat olarak sinema, geçmişte yaşanan travmatik olayları aktararak izleyicisine hem bilgi vermeye hem de o travmaya maruz kalan bireylerin acılarıyla yüzleşmesine yönelik bir köprü işlevi görmektedir. Sinemanın travmaları tedavi, şok, röntgencilik ve tanıklık stratejileri ile ele aldığı belirtilirken bu film tanıklık stratejisini 
takip eder. Toplumsal travmaların bireyler üzerinden incelenmesiyle birlikte ortak bir ses açığa çıkarılırken filmin açık uçlu sonu da bu travmaların devam ettiğine ve ancak toplumdaki madunların çığlıklarına kulak verildiğinde yüzleşme sağlanabileceğine yönelik bir işarettir. İncelenen ikinci film olan Yazı Tura, ideoloji-biçem ilişkisine yönelik önemli bir örnek olarak verilir. Her film politik ve ideolojik bir dünya kurarken Yazı Tura da biçemsel açıdan "yoğunlukla yakın plan çekimler, karakterlerin yüz ifadelerini, yaşadıkları sarsıntıları, travmanın kişinin zihninde her an yeniden tekrarlanışını, buradan kaynaklanan günlük yaşamdaki gerginlik, güvensizlik ve parçalanmışlık hissini öne çıkarır" (s. 48). Press filmi travmatik olaylar karşısında iktidarın manipülasyon gücünü basın üzerinden irdeler. İletişim kanallarına müdahale ile gerçek sadece engellenmez, aynı zamanda çarpıtılır ve değişime uğratılır. Press de tanıklık stratejisini kullanarak Güneydoğu'da yaşananları gazetecilerin bakış açısıyla sunar. Basının sunduğu olanaklar ile hem belge ve arşivleri görünür kılar hem de kurbanların bir araya gelip iletişim kurmasıyla paylaşılan belleğin güçlendirilmesini sağlar.

Işıklar Sönmesin filminde "diyalog mümkün mü?" sorusunun cevabı, filmin anlatı ve söyleminde aranmaktadır. Var olan çatışmanın kişilere indirgenmesiyle hikâyenin ve karakterlerin ne söyledikleri önem kazanmaktadır. Tedavi stratejisinin kullanıldığı filmde barış söylemi vurgulanmakta ve izleyici rahatlatılmaktadır. Buna karşın anlatı ve biçemde göze çarpan farklılıklar vardır. Film gerçekçi bir yüzleşme sağlayamaz. Fail-mağdur ikilemi ya da diyalog çabasının yerine resmi ideolojiyi yerleştiren Nefes: Vatan Sağolsun filmi ise şok etme stratejisini kullanarak şiddeti ön plana çıkarır. İlk bakışta amaç, şiddet üzerinden izleyiciyi şaşırtmak ve var olan travma üzerinden sarsmaktır. Şiddeti bir araç olarak kullanmaktan ziyade var olan şiddeti imlemek amaciyla kullanmak, akla eleştirel imge kavramını getirir. "İmgeyi egemenin elinden ve dilinden kurtararak eleştirel bir alımlamaya kapı açacak yeni bir temsil oluşturma niyetine sahip şiddet imgeleri de sinemada çokça karşımıza çıkar" (s. 91). Buna karşın filmdeki şiddet imgeleri, ötekileştirmeyi güçlendiren unsurlara dönüşür.

Tomris Giritlioğlu'nun yönetmenliğini yaptığı ve azınlıklarla ilgili farklı iki dönemi inceleyen Salkım Hanımın Taneleri ve Güz Sancısı filmleri, farklı stratejiler izler. Ulus devlete geçiş sürecinde azınlıklara yönelik ayrımcı politikaların ortaya çıkardığı "Varlık Vergisi"nin yaşattığı sıkıntıları anlatan Salkım Hanımın Taneleri, özellikle Nora Hanım'ın travmatik geri dönüşleri üzerinden acının günlük yaşama olan etkisini gösterir. Fakat tedavi stratejisi izleyerek bir ölçüde yaşanan acıları yumuşatması ve Hollywood sinemasına öykünen sinematografisiyle hikâyeyi ilginçleştirmeye çalışması, konunun yüzeysel biçimde ele alınması ile sonuçlanır. 6-7 Eylül olaylarını bir aşk hikâyesi üzerinden anlatan Güz Sancısı ise şok etme stratejisini uygulamasına karşın benzer bir yüzeyselleştirme çabası içermektedir. Var olan şiddetin daha çok izleyiciyi bilgilendirme düzeyinde kalması ve ideolojinin bireyler üzerinden temsil edilmesi gerçeğin manipülasyonuna ve arka plana atılmasına neden olmaktadır.

12 Eylül darbesine şok etme stratejisi üzerinden bakan Eve Dönüş filmi, sıradan bir karakter olan ve dönemin politik ikliminden mümkün olduğunca uzakta kalmaya çalışan Mustafa karakterinin örgüt üyeliğiyle suçlanıp işkence görmesini anlatır. İşkence sahnelerine 
uzunca bir süre yer verilmesiyle film, sıradan insanların bile iktidara tehdit olarak görülmesi halinde başlarına neler gelebileceğini anlatarak korkutucu bir uyarı işlevi edinir. "Böyle bir atmosferde filmin şok etkisiyle sarsacağı kitle hem o gün sessiz kalarak travmanın bir tarafında olan hem tüm travmayı doğrudan yaşayan hem de bugünün olayları deneyimlememiş ve hiç bilmeyen kitleleridir" (s. 126). Eleştirel imgenin bu film bağlamında sessizlik sarmalının bir sonucu olarak doğması, ilginç bir yaklaşımdır. Kitapta incelenen son film olan Sonbahar ise hastalığı nedeniyle hapishaneden tahliye edilen Yusuf'un eve dönüş öyküsüdür. Kullanılan çekim açıları ile eve dönen Yusuf'un sıkışmışlığını yansıtan film, tanıklık stratejisini kullanarak iktidarın baskısının psikolojik ve fiziksel boyutlarını izleyiciye aktarır. Cezalandırma sisteminin işlevsizliği ve beden üzerindeki tahakkümü tartışmaya açılırken, kapalı alanlar ile doğa ikilemi aracılığıyla da mahpusluk ile özgürlük arasındaki zitliklar perdeye yansir.

İncelenen tüm filmler bir arada ele alındığında bazı ortak noktaların dikkat çektiği görünmektedir. Genelde biz ve öteki arasındaki çatışmanın yer aldığı; çoğunluk-azınlık, devlet-terörist, Türk-Kürt gibi ikilemleri konu alan filmlerde travmanın ancak konuşularak, yası tutularak ve paylaşılarak aşılabileceği vurgulanmaktadır. Tedavi stratejisi izleyen filmler genel olarak ele aldıkları konuyu yumuşatma yolunu izlerken şok etme stratejisini izleyen filmlerin ise eleştirel imge oluşturma konusunda zorlandıkları ve hâkim ideolojiye karşı bir mesafe koyamadıkları göze çarpmaktadır. Toplumsal bellek üzerinden işlenen filmlerin on yıllara dayanan bir geçmişi olmadığı düşünülürse biçem ve içerik açısından çok yetkin örneklerle karşılaşmamamız anlaşılabilir bir durumdur. Fakat bunun bir yöntem olarak kullanılması ve olayların tam bir cesaretle ele alınamaması, Haneke'nin işaret ettiği tehlikeyi bize hatırlatmaktadır. Bir film, yetkin bir sinema örneği olarak tasarlansa bile izleyicilerine karşı sorumluluklara sahiptir.

\section{Nasıl Bir "Yeni Dönem Türkiye Sineması?"}

Türkiye sinemasında toplumsal olayları konu edinen filmlerin başlangıcı şüphesiz ki 90'l1 yılların öncesine dayanır. Özellikle 1960'lı yıllardan itibaren, 1961 Anayasası́nın da sağladığı görece özgürlük ortamında ideolojik konuları içeren filmlerin sayısında bir artış olmuştur. Politik içerikli kitapların basılmasının hız kazanmasının da etkisiyle bu dönem yetişen yönetmenler, "toplumsal düzeni nesnel ve devrimci bir bakış açısıyla yansıtırken özgün bir sinema dili oluşturmaya çalışmışlardır" (Daldal, 2005: 58). 12 Mart muhtırası sonrası daha çok belli yönetmenlerin kimliğinde cisimleşen bu ideolojik yaklaşım, zamanla ortadan kaybolmuş ve yer yer komedi filmlerinde politik taşlamalar aracılığıyla var olmuşlardır.

$\mathrm{Bu}$ noktada sorulması gereken en önemli sorulardan biri; 1990 'l1 yıllardan itibaren sinemamızı geçmişle yüzleşmeye yönlendiren ve "Yeni Dönem Türkiye Sineması"nın yeni anlatılara yönelmesine sebep olan unsurların neler olduğudur. Sönmez, kitabında bu gelişmelerin arka planını tam anlamıyla doldurmamakta, aynı dönemde tüm dünyada benzer bir yaklaşımın olduğunu belirtmektedir. 1990'lı y1llardan itibaren toplumsal bellek konusunun verimli bir çalışma alanı doğurduğu vurgulanmaktadır. Buna karşın Türkiye'de bu yüzleşmeye neden olan yerel nedenlerin varlığı belirsiz bırakılmıştır. Özellikle Türkiye 
sinemasının içerisinde yer alan politik içerikli değerli filmlere, isimlere ya da akımlara değinilmemesi, başlangıç noktası açısından bir muğlaklık yaratmaktadır. Kitap, bu eksiğine karşın son yıllarda genellikle yönetmen sineması bağlamında ele alınan ve Türkiye Sineması' nın farklı isimlerine ve yönelimlerine yer vermeyi başarmaktadır. Toplumsal bellekiktidar-medya ilişkisinin en uç noktalarda duyumsandığı bir dönemde sinemanın geçmişle yüzleşmesi ve "sessiz olaylar" olarak adlandırılan; yani herkesin bildiği ama kimsenin konuşamadığı olayları yansıtması şüphesiz çok değerlidir. Konu sessizlik olduğunda ise genellikle susturulanların -ya da madunların- kadınlar ya da farklı cinsel tercihleri olan bireyler olduğu gözden kaçmamalıdır. Nadir örnekleri bir kenara bırakırsak sinema da zaman zaman iktidarın dilini kullanmakta ve bahsi geçen bireylere söz hakkı tanımamaktadır. Toplumsal olayların sadece nasıl yansıtılacağı değil; kimlere söz hakkı verileceği de önemli bir sorun teşkil etmektedir.

Sonuç olarak; toplumsal belleğe dair bilinçdışına itilen gerçeklerin su yüzüne çıkarılmasında, sinemacıların da çaba göstermesi zaruridir. Ancak bu çaba, Sönmez'in kitabında da belirttiği gibi insanları tanıklık stratejisi üzerinden gerçeklerle yüzleştirerek ve derine gömülen acıların yasının tutulmasıyla; kısacası "travmayla barıştırarak" gösterildiği takdirde değerli olacaktır.

\section{Kaynakça}

Assmann, J. (2001). Kültürel Bellek. Çev. Ayşe Tekin. İstanbul: Ayrıntı Yayınları

Calhoun, D. (2009). "Michael Haneke discusses The White Ribbon", https://www.timeout.com/london/film/michael-haneke-discusses-the-white-ribbon1. Erişim Tarihi: 04.05.2018.

Daldal, A. (2005). 1960 Darbesi ve Türk Sineması'nda Toplumsal Gerçekçilik. İstanbul: Homer Kitabevi 